\title{
Factors Affecting Credit Officers' Performances in Commercial Banks in Ho Chi Minh City, Vietnam
}

\author{
Dinh Chi Thanh, Nguyen Thanh Binh
}

\begin{abstract}
The Vietnamese banking system was said to obtain some significantly successful results after the banking reform in the late 1980s when carrying on the two phases of Bank Modernization projects. This development of the "backbone" brings many benefits for the economy as well as significant challenges towards the bank system, primarily commercial banks. The success and failure of a commercial bank depend much on its employees' performance; therefore, in this paper, the author attempted to explore factors affecting credit officers' performance in commercial banks located in HCMC, Vietnam. The author applied the Quantitative method to explore five main factors, such as Leadership skills, Working environment, Compensation and Benefits, Promotion policy, and Training program, which affected credit officers' performances at Commercial Banks in HCMC. As a result, leadership skills, promotion policy and training program were the most affecting factors towards credit officers' performances at Commercial Banks in HCMC. Therefore, administrators of commercial banks have to enhance their senior managers' skills, rewards and promotion policies, and update their training programs regularly for employees to catch up with the quick changes of financial market in order to serve clients effectively as well as lure new ones.
\end{abstract}

Index Terms - Benefits, Compensation, Leadership skill, Promotion, Working environment.

\section{INTRODUCTION}

The role of commercial banks in developing the nation's economy is mainly the mediating financial role. With this role, commercial banks help operate investment capitals in the market. The distributed capital mechanism in the economy through the procedure of lending loans will help commercial banks evaluate financial risks.

Recently, most of the commercial banks at Ho Chi Minh City in Vietnam have reported that they have got loss as well as to have small profits because of not having increased credits as expected. Therefore, many commercial banks had many difficulties with output as there was not many loans so that they have had no profit as $80 \%$ of revenue of Vietnamese banks comes from profit of lending loans. It is also difficult for banks to reduce operation costs. Besides, there are still some indirect factors that Vietnamese economics has been developed sluggishly by low inflation indicators since November 2014.

Dinh Chi Thanh, Ph.D. Candidate, Lincoln University College, Malaysia.

Nguyen Thanh Binh, Dr.Ed.M. \& Lecturer, Tarlac State University, the Philippines.
Besides, in recent years, Vietnamese banks have to classify loans pursuant to new criteria and set up the high standby funds for risks. It causes them to increase the operating costs of banks. Therefore, the profit of banks also reduces remarkably. According to economic experts, the main reasons were that commercial banks had not anticipated risks, being greedy to mobilize capital, but they could not manage so that they had bad business results. Also, commercial banks are considered as financial moderators. The mediating role of a commercial bank is described by the bank's connection among subjects in an economic system, in which one side is the subject who has money, and another side is the subject which needs money. With the mediating role, commercial banks might receive many risks from two parties. To recognize risks in commercial banks' activities, managers of commercial banks should observe activities that their banks are performing and analyze risks in that activity process. In general speaking, the activities of commercial banks can be summarized by activities such as receiving deposits, payment, sponsoring, the business of foreign exchange, consulting, supplying financial services. Moreover, risks in commercial banks are caused by three reasons. The first one comes from the bank itself based on the structure of banks, management methods, managers' qualifications, ethics, and employees' qualification, bank's prestige. The second reason comes from clients, which are based on the business field, the scales of measurement of business, level of trustfulness, ability to pay. The final one derives from outside environment such as changing legislation, economics, politics, society, disasters, fires, etc. (Duyen, 2015).

Therefore, preventing and limiting credit risk is not only vital to the banks, but it is also the requirement of one nation's economy, contributing to stabilize and develop the whole society. Risk management aims to maximize profits after adjusting the risks of banks in their granted limitations. Policies to prevent and limit credit risks have to be studied to apply appropriately for each bank's business characteristics as credit officers in each bank play a vital role in risk management to prevent loss for banks as well as improve commercial banks' reputation and lure new clients.

\subsection{Leadership skills}

II. LITERATURE REVIEW

Leadership behavior was thought of as a process of directions for activities establishing a group to achieve the goals for its organization. The new focused point was marked as the initial approach of behavior. Nowadays, the latest trend is shifted to what a leader does instead of focusing on what a leader is. The two mostly applied patterns of leadership behavior affecting leaders' behaviors are job-centered form 
and employee-center ones. Leadership's skill is related to the ability of each individual to inspire confidence as well as supporting others within an organization to achieve their organization's goals (Dubrin, 2012).

In the currently severe competition market, leadership has become a vital key for any business. Every organization has to pay attention to direction to achieve its goals and ensure its stability. Leadership is defined as a process that influences employees within an organization to achieve its goal (Esmer et al., 2014). In other words, leadership is related to the ability to create supports and confidence needed to reach the organization's goal among employees (Dubrin, 2012). It is also a process that affects group members, guiding them in the right direction. A leader usually influences members of a group by using his or her ability to achieve the organization's targets. Directing members to reach the goals requires different persuasion skills. Leaders with these skills and the ability to persuade others can become leaders. Leadership is considered as a vital factor with a power influencing the others. Leaders and members of the organization create value together and become a trademark (Esmer et al., 2014). It can be said that leadership's competence may affect strongly employees' performance in commercial banks.

Hypothesis 1 (H1): There is a significant relationship between Leadership's skill and credit officers' performance.

\subsection{Working environment}

Many concepts were defined for the working environment in different contexts. According to Mai and $\mathrm{Vu}$ (2016), the working environment is considered as a physical geographical location, in which it can be the surroundings of a workplace such as a factory site or an office building. A positive working environment will make employees excited when they go to work and remain this motivation all day (Vuong. 2015). Also, for more particular interests, the ways in the working environment may influence the received information and resources, which are derived from two primary sources of relationships between managers and colleagues (Tran et al., 2018).

Besides, the quality of the working environment is said to depend on a combination of variables in the working atmosphere as it has an essential impact on an organization's commitment, working participation, and job performance (Hashempour et al., 2018). Therefore, in the quick changing era, the working environment requires managers of organizations to supply their employees not only good materials and salaries but also a friendly working environment, comfortable working spirit so that they can have the motivation to work and develop all their ability to help the organization to achieve its goals (Vuong, 2015). Therefore, it can be concluded that the working environment affects employees' performance significantly at work, especially towards credit officers at commercial banks in HCMC, Vietnam.

Hypothesis $2\left(\mathrm{H}_{2}\right)$ : There is a significant relationship between working environment and credit officers' performance.

\subsection{Compensation and benefits}

Every organization has many different goals, but there are also common goals transcending most organization's boundaries, such as profitability, longevity, growth, and mission of the organization (Vuong, 2015). For most organizations, it's vital to have an effective use of labor since the cost of labor becomes a major key in the cost equation. Most of managers and directors attempt to maximize labor output in all forms while minimizing the labor costs necessary to create the output. The main labor costs are said to derive from direct and indirect forms of compensation, usual wages, and fringe benefits. Besides, there are also other related costs, such as recruitment, selection, training, occupancy, and separation costs, etc. (William, 2007).

All managers need to maximize their organization's goal attainment and productivity by carefully evaluating both labor costs and output in all forms. Therefore, most managers and supervisors want to improve employees' performance levels, quality of products and services, waste reduction more rapidly than increasing their costs to deliver the output. It means that the use of compensation and benefit policies can improve output fields while controlling costs. As a result, this can enhance employees' motivation, attitudes, and performances at costs which are less than the gains from increasing labor output. Therefore, it can be said that the organization's compensation and benefits also affect its employees' performance at work.

Hypothesis $3\left(\mathrm{H}_{3}\right)$ : There is a significant relationship between Compensation and Benefits and Credit Officers' Performance.

\subsection{Promotion policy}

A promotion of an employee is regarded as that employee's advancement from one position to another job position with a higher salary range, more senior job title, and more responsibilities in an organization to manage or oversee other employees' work.

It can be seen that career development can provide beneficial opportunities for employees when joining in professional training and other types of professional development in order to achieve their advanced skills as well as taking greater responsibility at work, improving their status or earning higher income, all of which are aimed to develop their career (Mai et al., 2016). Moreover, organizations will become more effective and efficient if they have their professional employees who know how to use their skills and abilities in the workplace to handle tasks well as well as complete their roles successfully to develop their organizations (Mai et al., 2016). Therefore, promotion policies are welfare policies for employees to work, and it is not only crucial for any organization but also financial service businesses. Creating a promotion policy will help employees have the comfort to work effectively and serve clients better. It can be concluded that the promotion policy of the organization also affects employees' performance at work.

Hypothesis $4\left(H_{4}\right)$ : There is a significant relationship between promotion policy and credit officers' performance.

\subsection{Training program}

Nowadays, human resources are usually regarded as a critical factor in an organization's ability to build and sustain its competitive advantages as well as play a crucial role in any business enterprises. In a severely current competitive environment, every organization must pay attention to training and human resource development as 
human resources is the basis for the existence and development of the organization. By providing effective training, the organization will generate skilled staff for the whole organization to accomplish required tasks and also increase productivity (Thanh, 2015).

Training is regarded as systematic actions which help employees develop and improve their skill, knowledge and behaviors so that they can perform their jobs related to their duties as well as accomplishing specific tasks and meeting the quality requirements of human resource for the future (Bulut \& Culha, 2010). Training is an incentive method as well as an investment made by the employers, which may instill feelings of obligation among workers according to the exchange perspective (Malhotra et al., 2007). Training activity is a non-financial motivator and can also help foster commitment and loyalty among workers in an organization. Furthermore, confidence can be instilled in employees when the firm provided them with the required knowledge and skills to carry out their jobs as well as help them cope with rapidly changing technological and market conditions. Other researchers stated that there would be increases in commitment by training and development activities (Khan, 2016). Benefits from investment in training for employees can enhance an organization's performance by increasing employees' skills, knowledge, and motivation level, which leads to higher commitment and productivity. It can be said that the training program affects employees' performance strongly at work.

Hypothesis $5\left(H_{5}\right)$ : There is a significant relationship between training program and credit officers' performance.

\subsection{The conceptual framework of the study:}

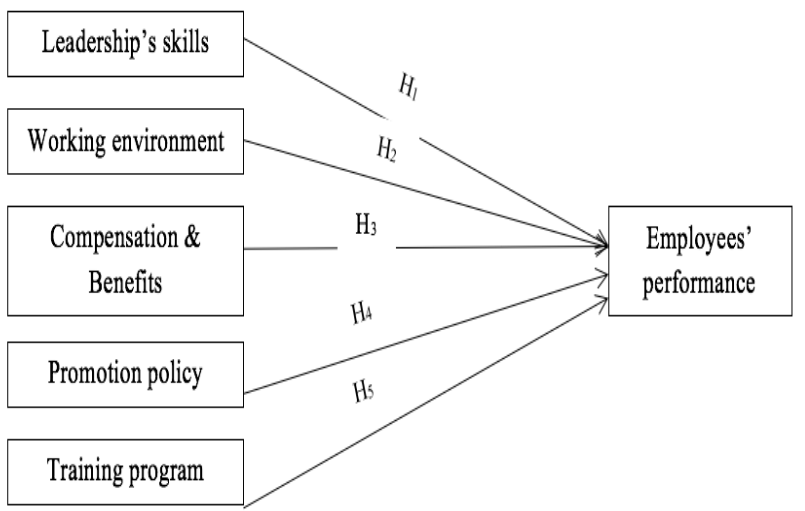

Figure 1.1: The conceptual framework of the sudy.

\section{RESEARCH METHODOLOGY}

This investigation was conducted through three phases. In the first phase, the author reviewed the related studies and found out factors affecting employees' performances. After studying and reviewing, the author presented 5 factors affecting to credit officers' performances at Commercial banks in HCMC-Vietnam, such as Leadership skills, Working environment, Compensation and Benefits, Promotion policy, and Training program. These 5 prediction variables will be expected to affect credit officers' performances at Commercial banks in HCMC, Vietnam.

In the second phase, the author would collect data from managers and clients at Commercial Banks in HCMC, such as Asian Commercial Bank (ACB), Bank of Investment and Development of Vietnam (BIDV), Saigon Thuong Tin Commercial Joint Stock Bank (Sacombank), and Vietnam Technological and Commercial Joint Stock Bank (Techcombank). The data was collected by the convenient method and 302 good samples were collected from 4 commercial banks for analysis. The author also used the 5-point Likert scale for analyzing the observed variables to explain the above factors. The scale was ranged from 1 (Completely disagree) to 5 (Completely agree).

The third phase would be implemented by analyzing the reliability of scale, EFA. After satisfying the coefficients of scales and standards for analyzing factors, the author continued to analyze the Multivariate Multiple Regression to check regression values. Therefore, the conceptual framework of this study was established as followings:

$$
\mathbf{Y}=\beta_{0}+\beta_{1} * X_{1}+\beta_{2} * X_{2}+\beta_{3} * X_{3}+\beta_{4} * X_{4}+\beta_{5} * X_{5}+\sigma
$$

While $\mathrm{Y}=$ Credit Officers' Performance (CRP);

$\mathrm{X}_{1}=$ Leadership Skills (LES);

$\mathrm{X}_{2}=$ Working Environment (WOE);

$\mathrm{X}_{3}=$ Compensation and Benefits $(\mathrm{COB})$

$\mathrm{X}_{4}=$ Promotion policies $(\mathrm{PRP})$;

$\mathrm{X}_{5}=$ Training program (TRP);

$\sigma=$ Error Term;

$\beta_{\mathrm{o}}=$ the intercept; $\beta_{1}, \beta_{2}, \beta_{3}, \beta_{4}$ and $\beta_{5}=$ the regression coefficients for the five dimensions of the IVs measures.

\section{RESULTS AND DISCUSSIONS}

\subsection{Result of analyzing the scale:}

Table 4.1: Result of analyzing the reliability of scales:

\begin{tabular}{|l|r|}
\hline \multicolumn{1}{|c|}{ Factors } & $\begin{array}{c}\text { Cronbach's } \\
\text { Alpha }\end{array}$ \\
\hline Leadership skills (LES) & .838 \\
\hline Working environment (WOE) & .823 \\
\hline Compensation and Benefits (COB) & .825 \\
\hline Promotion policies (PRP) & .800 \\
\hline Training Program (TRP) & .783 \\
\hline Credit Officers' Performance (CRP) &, 815 \\
\hline
\end{tabular}

From the Table 4.1, author analyzed the coefficients of Cronbach's Alpha of independent variables and dependent variable to test the reliability of scale and then removed variables with Corrected Item - Total Correlation < 0.3, except for variables with Cronbach's Alpha $\geq 0.7$. As seen in the above table, it can be said that coefficients of Cronbach's Alpha of all factors are all > 0.7 and factor loading $>0.3$. Therefore, the scales have the reliability and are all accepted for the next analysis. 


\subsection{Result of EFA}

Table 4.2: Coefficients of KMO and Barlett's Test

\begin{tabular}{|l|l|}
\hline \multicolumn{2}{|c|}{ KMO and Bartlett's Test } \\
\hline \multicolumn{2}{|c|}{ Kaiser-Meyer-Olkin Measure of Sampling } \\
Adequacy.
\end{tabular}

Result of KMO and Bartlett's Test in Table 4.2 showed that all variables have a mutual relationship ( $\operatorname{sig}=0.00<0.05$, accepting $\mathrm{H}_{1}, \mathrm{H}_{2}, \mathrm{H}_{3}, \mathrm{H}_{4}$, and $\mathrm{H}_{5}$ ). Concurrently, $\mathrm{KMO}=0.849$ $>0.5$ showed that analyzing factors to group variables together was proper and data was also suitable for the analysis. In addition, all factors had Eigenvalues $>1$. The Average Variance Extracted with $65.709 \%>50 \%$ was met the requirement. With the Principal components and Varimax by assigning the number of factors needing to be extracted, there were 5 factors extracted from observed variables. This showed that $65.7 \%$ of changes from the 5 extracted factors were explained by observed variables and values of observed variables explained the meanings of each factor.

\subsection{Regression analysis:}

Table 4.3: Evaluating the suitability of Multivariate Multiple Regression model:

\begin{tabular}{|c|r|r|r|r|}
\hline \multicolumn{6}{|c|}{ Model Summary $^{\mathbf{b}}$} \\
\hline Model & $\mathrm{R}$ & R Square & $\begin{array}{c}\text { Adjusted R } \\
\text { Square }\end{array}$ & $\begin{array}{r}\text { Std. Error of } \\
\text { the Estimate }\end{array}$ \\
\hline 1 &, $780^{\mathrm{a}}$ &, 660 &, 659 &, 094 \\
\hline \multicolumn{5}{|l|}{} \\
\hline
\end{tabular}

Table 4.3 showed that value of coefficient $\mathrm{R}$ was $0.660>0.5$; therefore, this is a suitable model to evaluate the relationship between independent variables and dependent one. Besides, value of Adjusted R Square was 0.659. The built Linear Regression Model was suitable with data $65.9 \%$. In other words, $65.9 \%$ of factor CRP was changed due to changes of independent factors such as Leadership skill (LES), Working environment (WOE), Compensation and Benefits (COB), Promotion policies (PRP), Training program (TRP) while $34.1 \%$ left was due to other factors.

Table 4.4: Result of regression weights

Coefficients $^{\mathrm{a}}$

\begin{tabular}{|c|c|c|c|c|c|c|c|c|}
\hline \multirow[t]{2}{*}{ Mod } & & \multicolumn{2}{|c|}{$\begin{array}{c}\text { Unstandardized } \\
\text { Coefficients }\end{array}$} & \multirow{2}{*}{$\begin{array}{c}\begin{array}{c}\text { Standardized } \\
\text { Coefficients }\end{array} \\
\text { Beta }\end{array}$} & \multirow[t]{2}{*}{$\mathrm{t}$} & \multirow[t]{2}{*}{ Sig. } & \multicolumn{2}{|c|}{ Collinearity Statistics } \\
\hline & & B & Std. Error & & & & Tolerance & VIF \\
\hline \multirow{6}{*}{1} & (Constant) & ,033 & ,024 & & 1,387 & ,166 & & \\
\hline & Leadership skills & 194 & ,005 & ,429 & 41,978 & ,000 & ,975 & 1,026 \\
\hline & Working environment & ,192 & 005 & ,373 & 36,355 &, 000 & ,968 & 1,033 \\
\hline & Compensation \& benefit & ,195 & ,005 & ,371 & 36,407 &, 000 & ,981 & 1,020 \\
\hline & Promotion policy & , 199 & 004 & ,477 & 46,677 &, 000 & ,975 & 1,026 \\
\hline & Training program & 203 & ,005 & ,453 & 44,741 & ,000 & 992 & 1,008 \\
\hline
\end{tabular}

a. Dependent variable: CRP

From the Table 4.4, it showed that all sig. values of the five factors were $<0.05$. Coefficient of VIF was $<2$ so that there was no phenomenon of multicollinearity statistics. The coefficient $\beta$ of LES was 0.429 , WOE was 0.373 , COB was 0.371 , PRP was 0.477 , and TRP was 0.453 .

Based on Table 4.4 and from the analysis in the regression model, the Linear Regression Model of factors affecting CRP in Commercial banks in HCMC with the standardized coefficients as followings:

$$
\begin{aligned}
& Y=\beta_{0}+0.429 * X_{1}+0.373 * X_{2}+0.371 * X_{3}+0.477 * X_{4}+ \\
& 0.453 * \mathbf{X}_{5}+\sigma \text {. }
\end{aligned}
$$

Therefore, from the regression analysis, it can be said that Credit Officers' Performance with 5 above factors, such as Leadership skill (LES), Working environment (WOE), Compensation and Benefits (COB), Promotion policies (PRP), Training program (TRP), affected positively to Credit Officers' Performance (CRP). The author suggested that managers and administrators of Commercial Banks in HCMC should have strategies to improve the 5 mentioned factors in order to enhance their employees' performances so that it will help banks control risk management, serve clients 
better, as well as attract new clients and investors in era of fast changes of financial service market nowadays.

\section{CONCLUSIONS}

As analyzed above, it can be seen that all factors with valuable scales met the reliability and validity requirement. When applying EFA, all factors had the distinguished values while in a factor the observed variables satisfied contributions for each factor's meanings. The statistical coefficient had good values and there was no removed factor. In addition, the proposed hypothesis was that 5 factors: Leadership skill (LES), Working environment (WOE), Compensation and Benefits (COB), Promotion policies (PRP), Training program all affected Credit Officers' Performance (CRP) with all values of 5 factors with P-value $<0.05$ so that all proposed hypotheses in this study have the statistical meanings.

The author attempted to explore factors influencing credit officers' performances of Commercial Banks in HCMC, Vietnam. As a result, the most strongly and positively affecting factor was Promotion policy (PRP) with $\beta=0.477$; the second positively affecting factor was Training Program (TRP) with $\beta=0.453$; the third affecting factor was Leadership skills (LES) with $\beta=0.429$, the fourth affecting factor was Working Environment (WOE) with $\beta=0.373$, and the final one affecting strongly to Credit Officers' Performance was Compensation and Benefits (COB) with $\beta$ $=0.371$.

From the findings, it can be said that in order to improve credit officers' performance at Commercial Banks in HCMC, administrators and managers should pay attention to these above factors and adjust their policies to encourage their employees to work more effectively with rewards and promotion policy. In addition, administrators and managers of Commercial Banks also have to improve the following basic issues:

Firstly, administrators should develop and improve their managerial skills and create the working motivation for their employees. Administrators should manage their banking branches with democratic style to create the positive spirit for staff to perform well so that they can make clients' satisfaction more and these lead to clients' loyalty to that bank. They should also turn over the authority to staff as well as inspire and encourage them in the working process to serve clients better.

Secondly, managers and supervisors at each branch of Commercial Banks must ensure the risk communication procedure utilized to be effective. This will help create transparent information process from the leaders to officers to minimize the gap in risk information. Department of risk management has to update sources of information about financial risks and immediately reflect potential risk activities as the business environment changes to their credit officer timely. This procedure has to be announced widely and identically throughout their branches with good e-banking system.

Thirdly, the training system for banking employees should be supported greatly from the top managers of commercial banks at the emotional level as well as the contents of training must involve problem solving, risk management, communication skills, which are all related to the aim to develop the professional qualification for employees at work.

Finally, open-minded spirit at work will help staff have the comfortable mentality to develop their creativity and work better. Managers have to create unity in the internal division and prevent conflicts among staff. All bank tellers, credit officers and other employees have to support, learn from each other, unite and have responsibility to help each other at work. It is the key for each member to improve their expertise skill, working experience, which create teamwork's strength in order to develop their financial organization more and more. Besides, the senior always supports and creates working conditions for the subordinate to develop their competence. From the above issues, those will be motivations for credit officers, bank tellers, and other staff to develop their latent potentials effectively to enhance commercial bank's reputation and advantages for competitive competence in the context of international integration in Vietnam.

\section{LIMITATION AND SUGGESTION}

This study was conducted as an exploratory research by the author although there are many other factors affecting to performance of Commercial banks. Therefore, Vietnamese banking organizations or Vietnam Bank of State should implement future studies about service quality and risk management regularly to improve existing banking system throughout Vietnamese Bank system as well as investigate other factors related to credit officers' performance such as Qualification, Experience, and Leadership style at Commercial Banks when comparing with their training programs.

\section{REFERENCES}

[1] Bulut, C., \& Culha, O. (2010). Training in Organizational Commitment. International Journal of Training and Development. Vol. 14(4): pp. 309-322.

[2] Dubrin, A. J. (2012). Leadership: Research findings, Practices and Skill. $7^{\text {th }}$ Edition. South Western Cengage Learning.

[3] Duyen, T. T. (2015). Leadership competence of senior managers of bank for investment and development of vietnam (bidv): basis of a traning program. Unpublished dissertation of Tarlac State University, The Philippines.

[4] Esmer, Y., and Dayi, F. (2014). A new paradigm in management: Ethical Leadership, $12^{\text {th }}$ International Academic Conference. Pp. 399-413 Prague: IISES.

[5] Hashempour, R., Hosseinpour, G. H., Etemadi, S., \& Poursadeghiyan, M. (2018). The Relationship between Quality of Work Life and Organizational Commitment of Iranian Emergency Nurses, Health in Emergencies \& Disasters Quarterly (HEDQ), Vol. 4 (1): pp. 49-54.

[6] Huerta, M. E., Audet, X. L., \& Peregort, O. P. (2006). In-company training in Catalonia: Organizational structure, funding, evaluation and economic impact. International Journal of Training and Development, Vol. 10(2): pp. 140-163.

[7] Khan, M. A. (2016). Enhancing Effectiveness of Employees through training and development in the Healthcare Department of Khyber Patchtrunkhwa Pakistan: A literature review. International Review of management and Marketing. Vol. 6(4): 731-737.

[8] Mai, N. K., and Vu, H. Y. (2016). Investigate the Effects of Job Stress on Employee Job Performance: A Case Study at Dong Xuyen Industrial Zone, Vietnam. International Journal of Trade, Economics and Finance, Vol. 7(2): pp. 31-37.

[9] Malhotra, N. K. (2007). Marketing Research: An Applied Orientation. Pearson Publication. 
[10] Thanh, T. D. (2015). An analysis of improving the quality of Human Resources in Ben Thanh Group, Vietnam. Unpublished Dissertation, Tarlac State University. The Philippines

[11] Tran, K. T., Nguyen, P. V., Dang, T., \& Ton, T. (2018). The Impacts of the High-Quality Workplace Relationships on Job Performance: A Perspective on Staff Nurses in Vietnam. Behavioral sciences: Basel, Switzerland, Vol. 8(12): pp. 109-111.

[12] Vuong, K. T. (2015). An exploration of the customer behavioral model for E- Marketing strategy in Vietnam. An exploration of the customer behavioral model for e- marketing strategy in Vietnam, Vol. 8(23): pp. 97-104.

[13] William, A. S. (2007). The Impact of Corporate Compensation and Benefit Policy on Employee Attitudes and Behavior and Corporate Profitability. Journal of Business and Psychology. Vol. 2(1): pp. 8-28. 